\title{
Rural livelihoods and mangrove degradation in south-west Madagascar: lime production as an emerging threat
}

\author{
Ivan R. Scales, Daniel A. Friess \\ LEAh GLass and LaLaO Ravaoarinorotsinoarana
}

\begin{abstract}
Mangroves are heavily threatened globally, with fuelwood harvesting and charcoal production a growing threat in low-income nations. However, the socio-ecological dynamics of mangroves are poorly understood, especially the roles of poverty and wealth in shaping resource use. This is particularly the case with Madagascar's mangroves, which contribute $2 \%$ of global mangrove cover. We report on the use of and threats to mangroves in the Bay of Assassins in south-west Madagascar. We document the production of sokay, a sea-shell based lime produced in mangrove wood kilns and used as a render on houses to improve their durability. Lime rendered houses are considered a status symbol. Growth in the use of lime is related to a rise in income in some households, which is partly a result of the increased commodification of marine products such as octopus, seaweed and sea cucumber. These products have experienced rapid commercialization over the last decade, with fishers now supplying global markets. We also document evidence of the emergence of larger-scale lime production. The growth of lime production has major ramifications for mangrove cover. We have observed a worrying development in mangrove harvesting patterns tied to lime production, where mangrove ecosystems are cleared instead of selectively cut. We consider the implications of our findings for broader debates about the relationship between conservation, poverty and natural resource use. We highlight research priorities and discuss the policy implications of our research, especially the need for the integrated management of ecosystems.
\end{abstract}

Keywords Biodiversity, conservation-poverty linkages, deforestation, Madagascar, mangrove use, migration, povertyenvironment linkages

Ivan R. SCALES (Corresponding author) Department of Geography, St Catharine’s College, Cambridge, UK. E-mail irs28@cam.ac.uk

Daniel A. Friess Department of Geography, National University of Singapore, Singapore

Leah Glass and Lalao Ravaoarinorotsinoarana Blue Forests Project, Blue Ventures Conservation, Toliara, Madagascar

Received 2 August 2016. Revision requested 9 September 2016.

Accepted 22 November 2016. First published online 11 April 2017.

\section{Introduction}

Clobally, mangrove ecosystems are heavily threatened $\mathcal{J}$ (Duke et al., 2007). Although aquaculture has been the biggest proximate driver of mangrove loss in many regions (Walters et al., 2008; Richards \& Friess, 2016), harvesting of mangroves for fuelwood and charcoal production is a growing threat in low-income nations (UNEP, 2014). Deforestation and degradation of mangroves have serious socio-economic implications linked to the loss of important ecosystem services, including the provision of building materials, fuelwood, charcoal, fish and shellfish (Walters et al., 2008; Barbier et al., 2011). Other services include storm protection, carbon storage and a range of cultural services (Barbier et al., 2011; Costanza et al., 2014).

Despite their importance, the socio-ecological dynamics of mangroves are poorly understood (Bandaranayake, 1998; Walters et al., 2008). Madagascar's mangrove ecosystems, which make up $2 \%$ of global cover, remain particularly understudied (Giri \& Muhlhausen, 2008; Harris, 2011). They are increasingly threatened by conversion to agriculture and charcoal production (Giri \& Muhlhausen, 2008; Jones et al., 2016), although there are considerable geographical variations in socio-ecological dynamics (Jones et al., 2016). Given the central role mangroves play in the livelihoods of many coastal communities in Madagascar, there is a need to better understand the drivers of coastal resource use and the socio-ecological dynamics of the island's mangroves. Here we document research on an emerging threat to mangroves in the Bay of Assassins in south-west Madagascar (Fig. 1): the production of sokay, a sea-shell based lime render produced in mangrove wood kilns and used to improve the durability of houses. We consider data from a vegetation survey conducted in August 2015; 15 semi-structured interviews with key informants (including six involved in lime production) undertaken in four villages (Ampasimara, Lamboara, Tampolove and Vatoavo) in August 2015; and data from surveys and interviews carried out in 2006 (Epps, 2007) and 2014 (Blue Ventures, 2015).

\section{The Bay of Assassins}

The Bay of Assassins (Helodrano Fanemotra in Malagasy) is a coastal inlet in south-west Madagascar, $180 \mathrm{~km}$ north of 


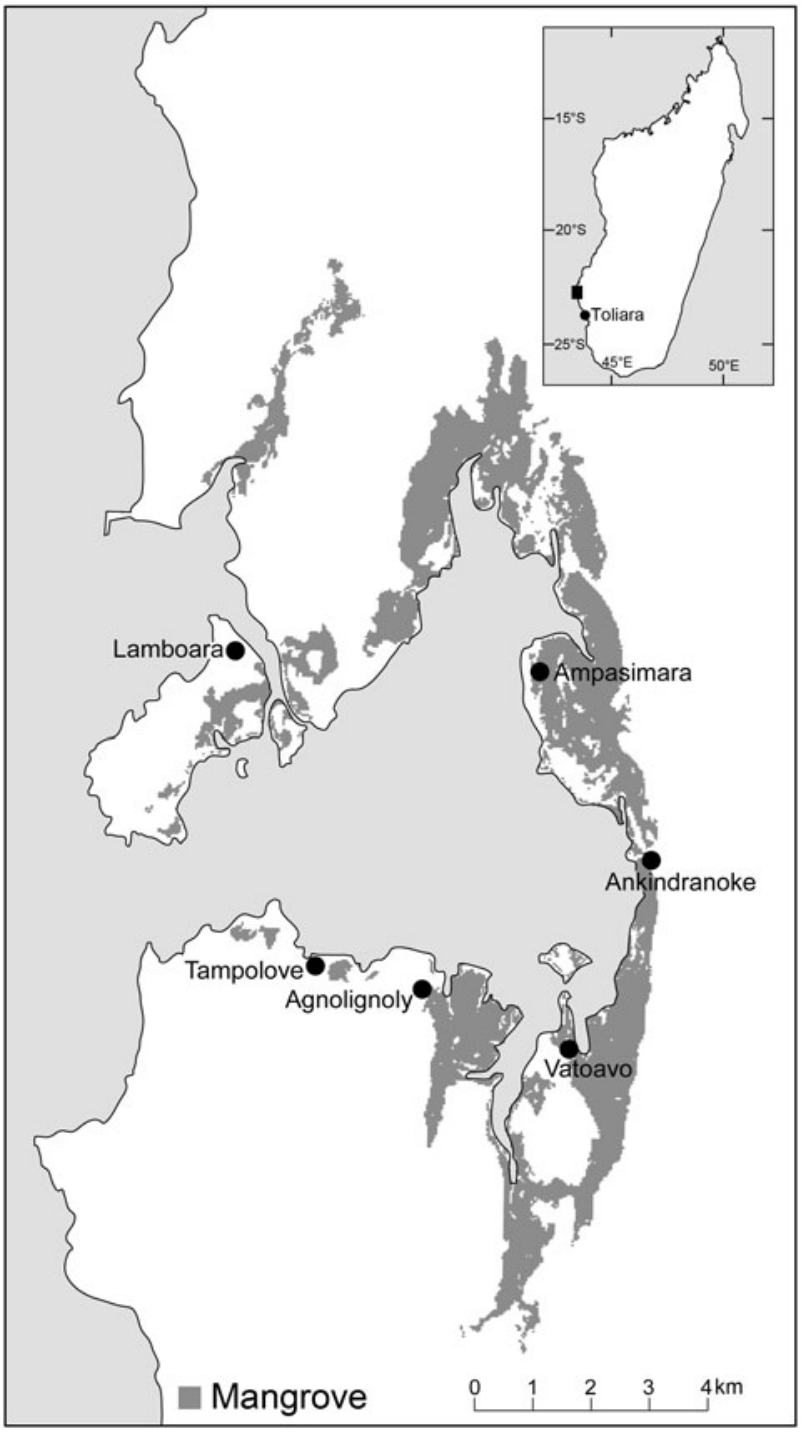

FIG. 1 The Bay of Assassins, south-west Madagascar (mangrove cover data from Blue Ventures Conservation).

the regional capital of Toliara. The inlet is fringed by c. 1,300 ha of mangrove (Jones et al., 2016), dominated by Ceriops tagal and Rhizophora mucronata. There are 10 villages around the bay, with a total population of c. 3,000 (Peabody \& Jones, 2013). Small-scale fisheries generate over $80 \%$ of household income in these communities (Barnes-Mauthe et al., 2013).

Coastal areas in Madagascar are increasingly experiencing in-migration, as poor agricultural households move to the coast seeking more secure livelihoods (Bruggemann et al., 2012). Data are scarce, but there is evidence that the Bay of Assassins is experiencing significant in-migration. For example, in the villages of Lamboara and Ampasilava $<30 \%$ of inhabitants were born in those settlements (Epps, 2007). The region's arid climate and the growth in marketing opportunities for marine produce have encouraged people to turn from inland agriculture to coastal fishing

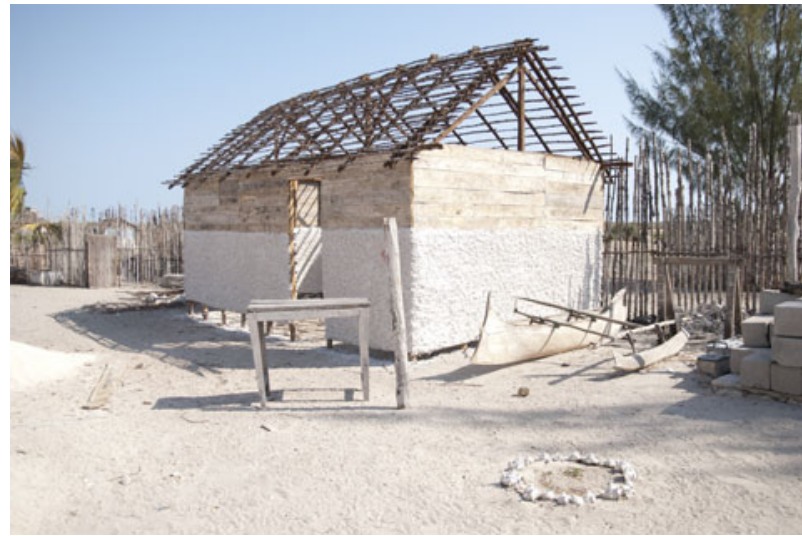

Plate 1 A house wall with wooden frame and lime render.

(Aina, 2010). Coastal in-migration and the commodification of marine resources in south-west Madagascar have in turn led to increasing pressure on fisheries (Aina, 2010; BarnesMauthe et al., 2013).

\section{Mangrove use in the Bay of Assassins}

Mangrove wood is harvested for two main purposes: the construction of houses and as a fuel in the construction of kilns to produce lime render. To estimate the effects of harvesting on mangroves we conducted measurements of canopy cover, structure and species composition in 60 randomly selected $7-\mathrm{m}$ radius circular plots within the bay. We counted, identified to species level, and measured the diameter at breast height of every tree (non-harvested and harvested). From our vegetation survey we found that every plot contained harvested trees, even those that were densely vegetated and relatively difficult to access. We found that the majority of tree harvesting involves the select felling of trees within mangrove stands, rather than clear cutting larger areas. Our mangrove plots had a mean canopy cover of $73.5 \pm \mathrm{SE} 3 \%$, with a mean of $28.7 \pm \mathrm{SE} 2.5 \%$ of trees $(>5 \mathrm{~cm} \mathrm{dbh})$ harvested. Although harvesting involves mostly cutting trees at the trunk and thus killing the tree (as Rhizophoraceae do not coppice or re-sprout), the forest is generally cut in a way that leaves the majority of trees intact.

\section{Lime production and use}

During our visits to four villages we observed that houses in the Bay of Assassins were made from a wide range of materials, including reeds, wooden planks, corrugated iron sheets, and lime render over a wooden frame (Plate 1). Our interviewees stated that lime render was the preferred wall material because of its relative durability. However, lime production is a time consuming process, requiring kiln makers to cut a large volume of mangrove wood and collect sacks of sea shells. This means that the use of lime 
is limited to wealthier households who can afford to pay others to produce it.

We observed 10 kilns, at various stages of construction, in four villages. A lime kiln (Plate 2) measures c. $2.6 \mathrm{~m}$ in length, $2.3 \mathrm{~m}$ in width and $1.2 \mathrm{~m}$ in height, using mangrove poles of c. $10 \mathrm{~cm}$ diameter. Layers of sea shells are sandwiched between layers of wood. Favoured sea shells are those from gastropods such as Terebralia palustris and Murex ramosus (Epps, 2007). However, the kiln makers we interviewed reported that these species were increasingly difficult to obtain and that they were reliant on bivalves such as Donax faba, which are considered inferior because of their smaller and thinner shells.

The preferred species of mangrove wood for kiln construction is Rhizophora mucronata, because of its high calorific value, although we noted that other species, such as Ceriops tagal, were also used. Kiln construction requires c. 120 poles of mangrove wood, with a total volume of c. $2.5 \mathrm{~m}^{3}$. A typical kiln produces $35-40$ rice sacks of lime. An average sized house requires c. 70 sacks to render. Each sack of lime sells for c. MGA 1,000 (USD 0.3). A house thus costs c. MGA 70,000 (USD 20) to render. To put this in perspective, the average annual income in south-west Madagascar is $<$ USD 200 per person (INSTAT, 2010) and households spend $>70 \%$ of household income on food (WFP, 2011).

As well as improving the durability of houses, lime render is also considered a status symbol. Interviews with key informants suggested that lime use had increased over the previous decade. This is supported by previous household surveys. In 2006, $28 \%$ of households in Lamboara village owned buildings with lime render invested in their construction (Epps, 2007). By 2014 this figure had gone up to 65\% (Blue Ventures, 2015). Furthermore, interviews revealed that since 2010 lime producers have sold lime to individuals from outside the Bay of Assassins, providing evidence of a lime commodity network that extends beyond the Bay.

Key informants suggest that growing wealth from sea cucumber (Holothuria spp.) and seaweed Kappaphycus alvarezii aquaculture, along with octopus Octopus cyanea fishing, has contributed to growing demand for lime as some households can afford to pay others in the village to produce it. All three of these marine products have experienced rapid commodification, with fishers now supplying global markets. For example, commercial trade in octopus only started in 1994 in the region, with export trade starting in 2003 and middlemen visiting villages to collect fresh octopus for export (Aina, 2010).

\section{Lime production as a threat to mangrove quality and quantity}

Changes in lime production and use have important implications for mangroves. Our vegetation surveys show that

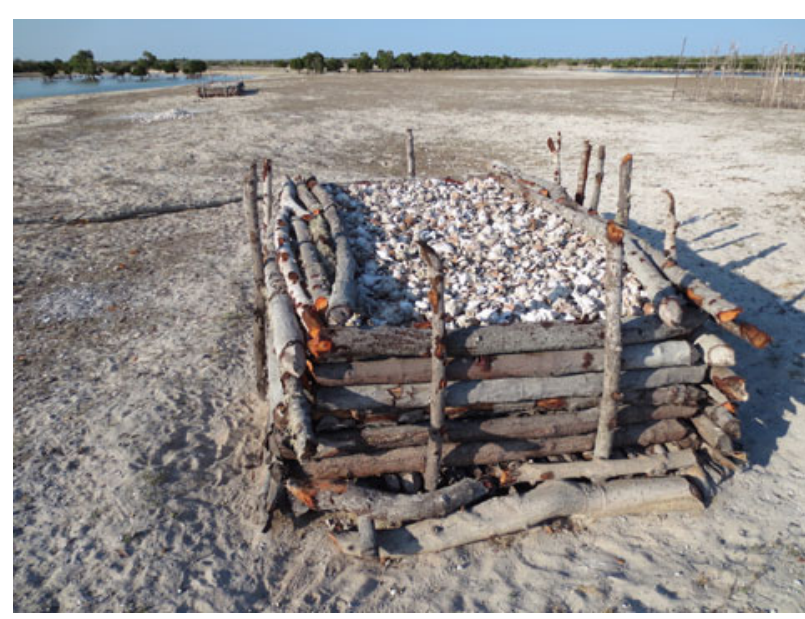

Plate 2 A lime kiln in the Bay of Assassins.

although the mangroves of the Bay of Assassins are heavily harvested, this mostly involves selective cutting, resulting in low-level disturbance. However, recent lime production has led to the clear cutting of mangrove forest in some instances. The area shown in Plate 3 (a total of 1.5 ha) was cleared in 2013 to fulfil a large commercial order from outside the villages. Although this is a small area, there are long-term implications for the site as canopy clearance often results in substantial surface subsidence (sensu Lang'at et al., 2014; Sasmito et al., 2016) limiting seedling regeneration, even after 3 years.

\section{Mangrove use and environmental policy in the Bay of Assassins}

We have documented lime production and consumption and how it relates to mangrove forests in the Bay of Assassins. Socio-economic surveys (Epps, 2007; Blue Ventures, 2015) and interviews with key informants suggest that the use of lime render has increased as a result of a rise in the income of some households. This relates in part to new sources of income that have been created as villages in the Bay of Assassins have become connected to global commodity chains for octopus, seaweed and sea cucumber.

This research has highlighted the complex relationship between poverty, income growth and resource use. Our findings suggest that it is not simply poverty that drives patterns of mangrove use and change in the Bay of Assassins. Rising incomes have created new pressures in the form of demand for lime render, which is met by other households who produce it commercially. While research on charcoal production in communities inland has found that it is carried out primarily by poor households who have abandoned farming (Gardner et al., 2016), the socio-economic characteristics of lime producers is not yet known. Mangrove wood use needs to be quantified through a comprehensive household survey and particular attention needs to be paid to 


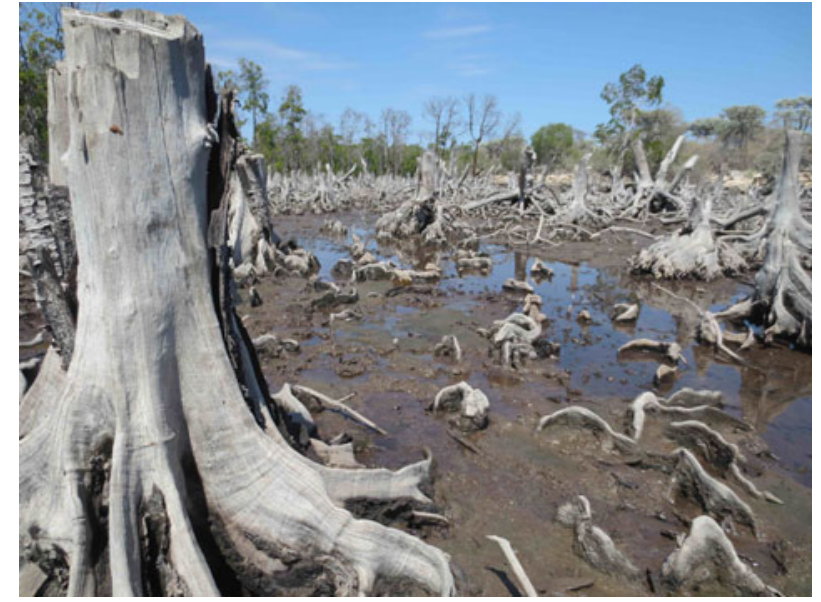

Plate 3 Clear cutting of Rhizophora mucronata and Ceriops tagal in response to demand for lime in 2013.

differences between households in lime production and consumption, for example according to wealth and migration status. If migration into coastal villages continues, incomes rise, and demand for building timber and lime render grows, how can mangrove harvesting patterns and rates be managed in such a way as to allow mangrove regeneration?

We have also found that lime commodity chains extend outside the villages of the Bay of Assassins. External demand has led to a different harvesting pattern, with mangrove clearance rather than selective cutting. The extent of lime commodity chains and the size of the market for lime is unknown. There is also a need for research on the socioecological dynamics of sea-shell collection, particularly the quantity and species of molluscs targeted, how shell collectors are responding to scarcity, and the ecological impacts of shell collection.

Our findings suggest that mangroves must be managed as part of broader landscape-based approaches. There is now abundant research showing that mangroves are interlinked with other ecosystems in important ways; for example, mangroves act as hatcheries for coral reef and pelagic fish species (Nagelkerken et al., 2008). Our documentation of lime production shows that links between ecosystems are also socio-economic. Changes in one system (e.g. growing income from aquaculture) can affect another (e.g. loss of mangrove cover through increased demand for lime). In turn, the loss of mangroves has implications for fisheries because of the role of mangroves in the life cycles of fish and other marine fauna important to the livelihoods of rural households in fishing communities (Duke et al., 2007; Nagelkerken et al., 2008). In the Bay of Assassins livelihoods draw on coral reefs, sea grasses, mangroves and terrestrial dry forests (Epps, 2007; Cripps \& Harris, 2009; Peabody \& Jones, 2013). It is therefore crucial that environmental policy considers marine resources (fisheries and aquaculture), terrestrial forests, and mangroves at the same time and examines links between them.

\section{Acknowledgements}

This research was funded through an Environment and Sustainability Grant from the Royal Geographical Society (with IBG). We thank Michael Strongoff, Jose Njara Ranaivoson and Helen Scales for field assistance, $\mathrm{Al}$ Harris and Blue Ventures for their logistical support, Philip Stickler (Department of Geography, University of Cambridge) for cartographic assistance, and two anonymous reviewers for their helpful comments and suggestions.

\section{Author contributions}

IRS and DAF designed the study, carried out the vegetation survey, analysed the data, and drafted the article. All authors contributed field observations and interview data, and read and revised the article.

\section{References}

Aina, T.A.N. (2010) Management of Octopus Fisheries off South West Madagascar. United Nations University Fisheries Training Programme, Iceland.

Bandaranayake, W.M. (1998) Traditional and medicinal uses of mangroves. Mangroves and Salt Marshes, 2, 133-148.

Barbier, E.B., Hacker, S.D., Kennedy, C., Koch, E.W., Stier, A.C. \& Silliman, B.R. (2011) The value of estuarine and coastal ecosystem services. Ecological Monographs, 81, 169-193.

Barnes-Mauthe, M., Oleson, K.L.L. \& Zafindrasilivonona, B. (2013) The total economic value of small-scale fisheries with a characterization of post-landing trends: an application in Madagascar with global relevance. Fisheries Research, 147, 175-185.

Blue Ventures (2015) Mangrove Use in the Bay of Assassins. Blue Ventures Conservation, London, UK.

Bruggemann, J.H., Rodier, M., Guillaume, M.M.M., Andréfouët, S., Arfi, R., Cinner, J.E. et al. (2012) Wicked socialecological problems forcing unprecedented change on the latitudinal margins of coral reefs: the case of southwest Madagascar. Ecology and Society, 17, 47.

Costanza, R., de Groot, R., Sutton, P., Sander van der Ploeg, S., Anderson, S.J., Kubiszewski, I. et al. (2014) Changes in the global value of ecosystem services. Global Environmental Change, $26,152-158$

Cripps, G. \& Harris, A. (2009) Community Creation and Management of the Velondriake Marine Protected Area. Blue Ventures Conservation, London, UK.

Duke, N.C., Meynecke, J.O., Dittmann, S., Ellison, A.M., Anger, K., Berger, U. et al. (2007) A world without mangroves? Science, $317,41-42$.

Epps, M. (2007) A Socioeconomic Baseline Assessment: Implementing the Socioeconomic Monitoring Guidelines in Southwest Madagascar. Blue Ventures Conservation, London, UK.

Gardner, C.J., Gabriel, F.U.L., St John, F.A.V. \& Davies, Z.G. (2016) Changing livelihoods and protected area management: a case 
study of charcoal production in south-west Madagascar. Oryx, 50, 495-505.

Giri, C. \& Muhlhausen, J. (2008) Mangrove forest distributions and dynamics in Madagascar (1975-2005). Sensors, 8, 2104-2117.

HARRIS, A.R. (2011) Out of sight but no longer out of mind: a climate of change for marine conservation in Madagascar. Madagascar Conservation \& Development, 6, 7-14.

INSTAT (2010) Enquête Periodique aupres des Menages 2010. Institut National de la Statistique, Antananarivo, Republique de Madagascar.

Jones, T.G., Glass, L., GANDhi, S., Ravaoarinorotsihoarana, L., Carro, A., Benson, L. et al. (2016) Madagascar's mangroves: quantifying nation-wide and ecosystem specific dynamics, and detailed contemporary mapping of distinct ecosystems. Remote Sensing, 8, 106.

Lang'at, J.K., Kairo, J.G., Mencuccini, M., Bouillon, S., Skov, M.W., Waldron, S. \& Huxham, M. (2014) Rapid losses of surface elevation following tree girdling and cutting in tropical mangroves. PLOS ONE, 9(9), e107868.

Nagelkerken, I., Blaber, S.J.M., Bouillon, S., Green, P., Haywood, M., Kirton, L.G. et al. (2008) The habitat function of mangroves for terrestrial and marine fauna: a review. Aquatic Botany, 89, 155-185.

Peabody, S. \& Jones, B. (2013) Plan d'Amenagement et de Gestion de la NAP Velondriake. Blue Ventures Conservation, London, UK.

Richards, D.R. \& Friess, D.A. (2016) Rates and drivers of mangrove deforestation in Southeast Asia, 2000-2012. Proceedings of the National Academy of Sciences of the United States of America, 113, 344-349.

Sasmito, S.D., Murdiyarso, D., Friess, D.A. \& Kurnianto, S. (2016) Can mangroves keep pace with contemporary sea level rise?
A global data review. Wetlands Ecology and Management, 24, 263-278.

UNEP (2014) The Importance of Mangroves: A Call to Action. United Nations Environment Programme-World Conservation Monitoring Centre, Cambridge, UK.

Walters, B.B., Rönnbäck, P., Kovacs, J.M., Crona, B., Hussain, S.A., BADOLA, R. et al. (2008) Ethnobiology, socio-economics and management of mangrove forests: a review. Aquatic Botany, 89, 220-236.

WFP (2011) Rural Madagascar Comprehensive Food and Nutrition Security and Vulnerability Analysis. World Food Programme, Antananarivo, Madagascar.

\section{Biographical sketches}

IVAN SCALES is a geographer specializing in environment and development issues, mostly in sub-Saharan Africa. His research emphasizes the role of political, cultural and economic factors in shaping the way natural resources are used and contested. He is investigating the diversity of environmental values, agriculture and food security, tropical deforestation, and community-based approaches to conservation. DANiel Friess is a tropical wetland geographer and Assistant Professor at the National University of Singapore. His research focuses on coastal ecosystem services, deforestation threats to mangroves, and wetland vulnerability to sea level rise. LEAH GLAss's current research interests include the intrinsic relationship between coastal populations and marine resources, and the spatial analysis of resource dynamics, with a particular focus on mangroves and their fisheries. LALAO RAVAOARINOROTSIHOARANA's research focuses on the assessment of marine ecosystem services, with a particular focus on mangroves, and the links between these resources and local socioeconomic trends. 